\title{
大容量直流変電所の短絡電流とそのしゃ断 方式
}

\section{1. まえがき}

部市通勒輸送区間にお的る大容量直流变電所の近 傍て短絡事故加発生した場合, 短絡電流はきわ力て大 で，条件によってはこの電流索しゃ断すべき高速传し 中断器のしゃ断容量を越える恐れがある。この多相整 流回路としての直流变電所の短絡現象の計算法々低圧

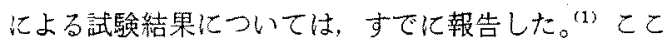
では具体的な大容量変電所の短絡電流を明らかにする ととあに，专の对策上してのインダクタンスそう入に 上る㧕制しゃ断法について報告する。

\section{2. 大容量直流変電所の短絡電流}

直流变電所の短絡電流は整流器の交流側と直流側の 回路定数が与元られれば求め引れる。交流側定数は交 流受電点の短絡容量, 整流器用変圧器の定数より容易 代求的られる。しかし直流側定数は実测化よる活かは 必ずしも容易には求められない。直流側定数は整流器 直流側出力端子より母線, 引出口を経て外線に出，上 ロリーへの第 1 き電分岐点化到る部分 (帰回路を含む) のインピーダンス，すなわち，第 1 き電分岐インピー ダンスともいうべきので，その実測值は神田変笔所 に书けるあのが唯一のものである。 $(0.2 \mathrm{mH} ， 5.5$ $\mathrm{m} \Omega)^{(1)}$ この值はきわめて小さく，したがって，短絡電 流の大きさは交流側定数に大きく支配され，またその 初期立上り di/dtは直流側のインダタタンスに大き く支配され，と屯汇高速度しゃ断器によるし的断に大 きな影響を与える。以下，ての直流側定数の計算法と 短絡電流の計算結果汇ついて述へる。

\section{〈2.1〉第1 き電分岐インピーダンスの計算 代}

Short-circuit Current and its Interruption in Large Capacity DC Substation. By T. FUJIMURA, Member (Railway Téchn. ical Research Institute)

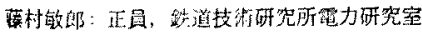

表的な大容量直流变電所の直流側インピーダンス，す なわ整流器一直流母線 $\rightarrow$ 第 1 き電分岐までのインピ ーダンス(引出口インピーダンス) の実測は, 測定法 このものは簡単であるが，数箇所にわたる営業線での 実測は容易ではないので，筫体の幾何学的配置を調查 して計算することとした。すなわち，椱数導体で構成 されるこの回路の等価的なインダクタンスの計算法上 しては正負導体群の配置仙応じ以下によった。

（1）正，負母線〜第 1 き電分岐間で平行と見なせ る部分については往復導体とし(1) 式によった。付 録突照)

$$
\begin{array}{r}
L=\left\{0.4 \log \left(d / \sqrt{a_{n} b_{m}}\right)+0.05(1 / n+1 / m)\right\} \\
(\mathrm{mH} / \mathrm{km}) \ldots \ldots \ldots \ldots \ldots \ldots . .(1)
\end{array}
$$

（2）前項において，正負導体の相対位置が直角， あるいは正または，負側の導体が単独に存在する場合 は，単独導体のインダクタンスとして（2）式によっ た。(付録参照)

$$
\begin{aligned}
& L=2 l\left\{\log \left(2 l / a_{n}\right)-1+1 / 4 n\right\} 10^{-4}(\mathrm{mH}) \cdot(2) \\
& \text { ただし, \{ \}内第 } 3 \text { 項は轨条の場合 } 0 \text { とする。 }
\end{aligned}
$$

（3）き電線と轨条が，通常の相対位置にある䇢所 は，単線区間で軌条の大地漏えいのない場合と見なせ るので

$$
L=1.6 \mathrm{mH} / \mathrm{km} \quad(50 \mathrm{~Hz} \text { 計算值 })^{(1)}
$$

を用いた。

実地調查した配線状態は相当繁䊒であるので，ここ では線采数，長さなどを要約した例走示すに止める。 (第 1 図参照)またこ机ら尊体の幾何学的配置加ら計算 したインダクタンス值と，神田に㧍ける测定值を第 1

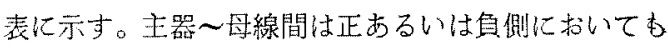
部分的には単独尊体の並列回路と見なせること，同一 ピット内往復導体のインダクタンスはほとんど無視で きることなどの点を考慮して有効なインダクタンス 


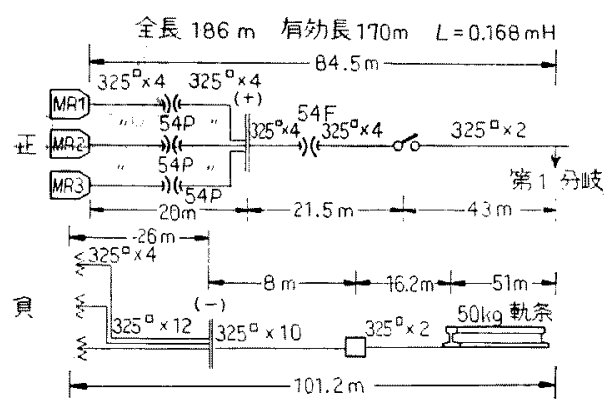

第 1 図 主器〜第 1 き電分岐間の導体配置

Fig. 1. Arrangement of conductors between rectifiers and the first feeding point.

を形成する等価的な導体長さに対するインダクタンス は，1䈏所を除きほぼ一定值で，平均值はこう長あた b

$$
L_{e}=2.1 \mathrm{mH} / \mathrm{km}
$$

となり，神田の测定值 $2.2 \mathrm{mH} / \mathrm{km}$ に近い值で，との 点からす計算結果は実際の值に近いむの上推定される と上もに，配線の長さ大からもだいたいのインダクタ ンス值の推定が可能と琶められる。短絡電流の立上り 初期を問題にする場合には，直流側インダタタンス は，0.1〜0.2 $\mathrm{mH}$ 程度を考膚すればよいであろう。

$\langle 2.2\rangle$ 大容量变電所の第1 分岐(引出口) 短絡電流 大都市通勤区間の大容量变電所の代表的な箅所已し て，7箘所の短絡電流を計算した。すなわち，その交 流側，直流倒定数より，整流回路を理想的な直流電源 と見なしたときの短絡電流,すなわち等洒短絡電流 $I_{d}$ を(4) 式より求力た。(1)

$$
\begin{aligned}
& I_{d}=\left(1-\varepsilon-R_{d^{\prime}} / L_{d^{\prime}} \cdot t\right) E_{d} / R_{d} \quad \ldots \ldots \ldots \ldots( \\
& \text { ただし, } \quad R_{d}{ }^{\prime}=R_{d}+R_{i}, \quad L_{d^{\prime}}=L_{d}+L_{i},
\end{aligned}
$$

$R_{d}$ : 直流側抵抗， $L_{d}$ : 直流㑡インダクタン ス, $R_{i}$ : 変電所整流回路の見加上口内部 抵抗 $=0.955 X+1.5 R_{a}, L_{i}$ : 变電所整流回

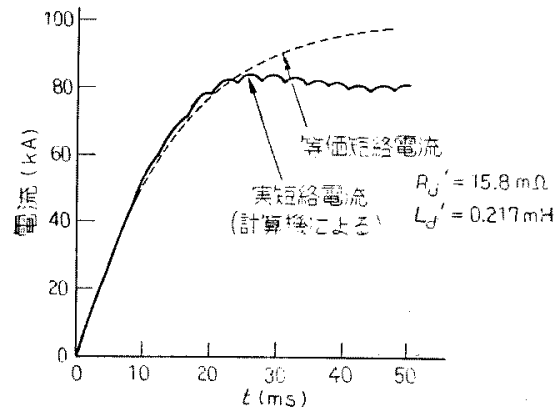

第 2 図 直流変電所短絡電流計算例 (C 变電所)

Fig. 2. Example of calculated short-circuit currents.

\begin{tabular}{|c|c|c|c|c|c|}
\hline 翌笪所 & 全弫 $l(\mathrm{~m})$ & 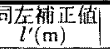 & 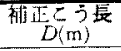 & 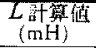 & $\begin{array}{c}L / D \\
(\mathrm{mH} / \mathrm{km})\end{array}$ \\
\hline A & 310 & 310 & 155 & 0.402 & 2.60 \\
\hline B & 143 & 136 & 68 & 0.130 & 1. 91 \\
\hline C & 186 & 170 & 85 & 0.168 & 1.97 \\
\hline D & 542 & 276 & 138 & 0.274 & 1.99 \\
\hline E & 249 & 249 & 125 & 0.250 & 2.00 \\
\hline F & 158 & 143 & 72 & 0.147 & 2.06 \\
\hline $\mathrm{G}$ & 160 & 160 & 80 & 0.176 & 2.20 \\
\hline
\end{tabular}

第 1 第 1 き電分岐インダクタンス

Table 1. Inductances for first feeding points.

\begin{tabular}{l|c|c|c|c|c}
\hline & & & \multicolumn{3}{r}{ 平均 $2.1 \mathrm{mH} / \mathrm{km}$} \\
\hline 神田 & 180 & 180 & 90 & $* 0.2$ & 2.2 \\
\hline 注 *印：剆定值
\end{tabular}

路の内部インダクタンス $=1.5 L_{a}, X:$ 交流 側りアクタンス, $R_{a}$ : 交流側抵抗， $L_{a}$ : 交 流側インダクタンス

結果を第 2 表にまた三相整流回路過渡見象として計 算機で計算した波形との比烄例を第 2 図汇示す。A変 電所を除き，いずれ屯直流側インダクタンスが小さい ため di/d $t$ が大であり，電流値む $10 \mathrm{~ms}$ で $30 \mathrm{kA}$ 以上上なる。第 1 き電分岥までの距離が異状に長いA 変電所を除き， $d i / d t$, 推定短絡電流之むにいわゆる 標準条件 $3 \times 10^{6} \mathrm{~A} / \mathrm{S} ， 50 \mathrm{kA}$ をこえている点，特に完 全短絡定常電流の小さいF变電所であそうである点が. 注目さ机る。

\section{3. 短絡電流の㧕制しゃ断法}

前述のような初期立上りの大きい大電流老低减，あ。 るいは㧕制しゃ断する方法としては，たと光ば下記の 方法加考えられる。

（1）直流母楾を分耀する

（2）抵抗しゃ断用し中断器の直列設置

(3) インダクタンスをそう入し，初期立上り $d i / d t$ 它㧕制寸る

第 2 表 大容量变雷所等俩短絡電流 (第 1 分岐)

Table 2. Equivalent short-circuit currents of large capacity substations.

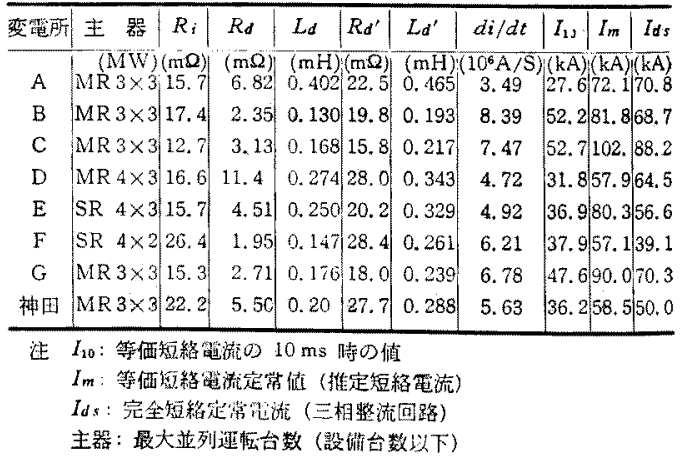


（1）の方法は，直流例同一母線につながる整流器の 並列台数が減るため，簡単化短絡電流を低減でるの で，実施可能な筒所ではすでに夷行栘されている。 ただし整流器，直流母線，引出回線之の相対位置の関 㥒で，構造的に母線分離不可能筒所力゙問題上して残 る。

（2）以下の方法はこれに対処するもので，並列抵抗 をそなえ，かつ開極速度の早いしゃ断器を良来のしゃ 断器と直列比新設する方法は二宫実験所での試駼結果 からは，短絡電流えのものの㧕制はできないか，しゃ 断時の限流值 (実しゃ断電流)，アークパワ，アークエ ネルギーの莇制に効果の方ることが確認されたが，各 '回線任抵抗しゃ断用しゃ断器を設置するわずらわしさ がある。

（3）の方法は，やはり短絡電流定常值の揤制は不可 能であるが，しゃ断時の限流值に密接に関係する電流 の初期立上り dild $t$ を㧕制する効果がある。これに より限流值とアークパワが揤制される。

〈3.1〉インダクタンスそう入による大電流しゅ断現 象への影影 インダクタンスを直流側にこう入した ときのしゃ瞇現象への影響を見るため，前記各変電所 に見か汁上の直流側インダクタンスが標準的な 0.5 $\mathrm{mH}$ になるように，新たにインダクタンスをそう入し たときのしの断時アークエネルギー，アークパワを非 三う入時上比較計算したものを第 3 表に，また計算波 形例第 3 図汇示す。

なお計算条件は下記の上おりである。このうちアー

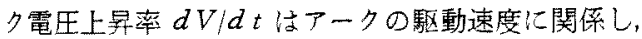
滒動速度は自励の場合はほ活電流化比例する。(2)また， しょ断器の構造によってお駆動速度は異なり， $d V / d t$ はしょ断器個有のあのであるが，開極電流にほぼ比例 するとの前提 ${ }^{(3)}$ で二宫実験所での従来の試験結果（第

第了表 インダクタンスそう入時のしゃ断現象 (計算値)

Table 3. Interrupting phenomena with additional inductance.

\begin{tabular}{|c|c|c|c|c|c|c|c|c|c|c|}
\hline \multirow[b]{2}{*}{ 変電形 } & \multirow{2}{*}{$\left(\begin{array}{l}I_{m} \\
(\mathrm{kA})\end{array}\right.$} & \multicolumn{3}{|c|}{ 実し。断電流 } & \multicolumn{3}{|c|}{ アークパワー } & \multicolumn{3}{|c|}{ アークエ秋ギー } \\
\hline & & $\begin{array}{l}L+d \\
(\mathrm{kA})\end{array}$ & $\begin{array}{l}L \quad 5 \\
(\mathrm{kA})\end{array}$ & 同比 & $\begin{array}{l}L \mathrm{~L} \\
\mathrm{MW}\end{array}$ & )$(\mathrm{MW}$ & 同比 & $\begin{array}{l}L+a \\
(W H)\end{array}$ & $\begin{array}{l}L \omega \\
\text { (W) }\end{array}$ & i) \\
\hline$A$ & 72.1 & 21.0 & 20.0 & 0.95 & 39 & 40 & 1.03 & 65 & 65 & 1.00 \\
\hline $\mathrm{B}$ & 81.8 & 39.0 & 21.5 & 0.55 & 68 & 44 & $|0.61|$ & 70 & 72 & 1.03 \\
\hline $\mathrm{C}$ & 102. & 36.5 & 22.0 & 0.60 & 72 & 48 & 0.62 & 80 & 78 & 0.98 \\
\hline D & 57.9 & 24.0 & 19.5 & 0.81 & 42 & 36 & 0.62 & 54 & 58 & 1.07 \\
\hline$E$ & 80.3 & 30.0 & 21.0 & $0 . \pi$ & 52 & 43 & 61 & 70 & 71 & 1,01 \\
\hline$F$ & 57.1 & 27.5 & 19.0 & $\therefore 54$ & 46 & 36 & $9.6 c^{\circ}$ & 55 & 58 & 1.05 \\
\hline$G$ & 90.0 & 32.0 & 21.5 & 367 & 63 & 45 & 061 & 75 & 74 & 0.99 \\
\hline 田 & 58.5 & 25.0 & 19.5 & 97 & 45 & 36 & $\therefore 61$ & 56 & $=9$ & 1.05 \\
\hline $\begin{array}{l}0.5 \mathrm{mH} \\
30 \mathrm{m \Omega} \\
1.620 \mathrm{~V}\end{array}$ & 54.0 & & 19.4 & & - & 35 & & - & ; 56 & 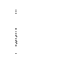 \\
\hline
\end{tabular}

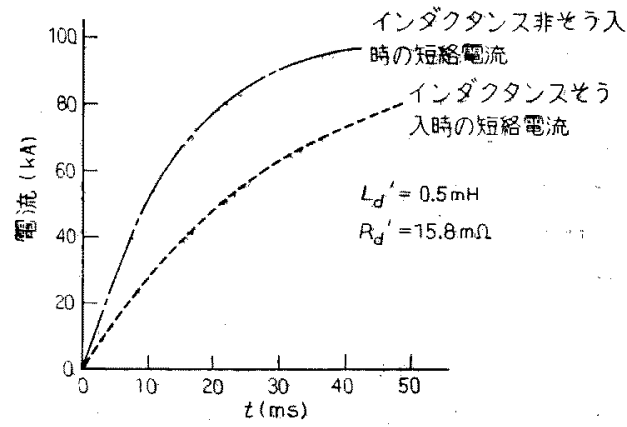

第3図 インダタタンスそう入時の短絡電流 (C変電所)

Fig. 3. Short-circuit current with additional inductance.

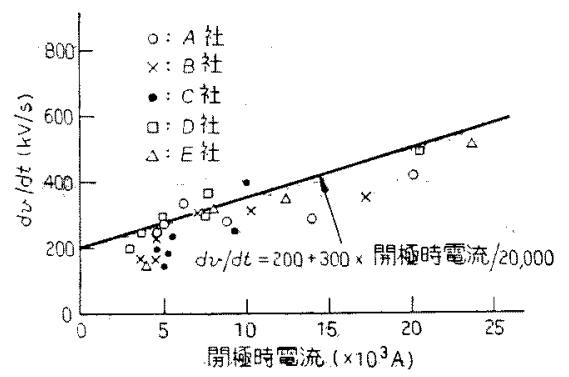

第 4 図しゅ断時のアーク電压上昇率

Fig. 4. Rate of rise of arc voltage at interruption.

4 図参照）より下記によった。こ机通常開極後の電 流变化の余りない領域でアーク電圧が上昇する点上り 予想できることである。

(1) し中断器目盛 $8,000 \mathrm{~A}$

（2）しゃ断器選択率は次による。すな水占， $\alpha$ $\leq 10$ では $100 \%, \alpha \geq 100$ では $50 \%, 100>\alpha>10$ て は直線的に変化するものとする。

ただし， $\alpha=R / L ， R ， L$ はしゅ断すべき回路の抵 抗とインダクタンス

(3) 開極幄机 $5 \mathrm{~ms}$

(4) アーク電王上景率

$d V / d t=200+300$, 開極特電流 $/ 20,000 \mathrm{kV} / \mathrm{s}$

(5) アー夕電生最大值 $3,000 \mathrm{~V}$

計算機による計算結果からは，インダクタンスそう 入により条件が相当綬和され

（i）限流值は大はば汇減少する

(ii) アークパワは約 $60 \%$ に減少する

(iii） アークエネルギーはほ上んど変化しない

（iv）標準条件 $(0.5 \mathrm{mH} ， 30 \mathrm{~m} \Omega)$ に対してはアー クパワ，エネルギーとも上回る。(最大 $40 \%$ 弱) 
少ことか明らかとなった。限流值ならびにアークパワ の)抑制が，しゅ断をどの程度谷易にするかは速断でき ないが，少くとあインダクタンスそう入により条件が 緩和されることは明らかであり，また過去の短絡発電 機による交流等価試験時には，前記インダクタンスそ う入時の計算值走上回るアークエネルギー，アークパ ワでもしゃ断可能であった点より，インダクタンスそ う入により大電流む現用しゃ断器でしゃ断可能である う。また，試験設備上，現在のわが国ではイシダクタ ンスが $0.5 \mathrm{mH}$ 程度であ执ば，推定短絡電流 $50 \mathrm{kA}$ 以上の大電流領域の父流等価試酸恮容易であるので,

との点から它直流側にインダクタンスをそう入する方 法はしゃ断を容易にする害兒可能かつ検証容易な力法 と考无ら机る。な拉 $0.5 \mathrm{mH}$ 上り大はばに小さい試験 についてはしゃ断器に並列に低インピーダンスを結ふ 交流等価試験法 ${ }^{(4)}$ があるが，電任，周波数の点で制約 を受ける标え机がある。

〈3.2〉可飽和インダクタンスそう入による大電流し や断現象への影響 可飽和インダクタンスをそう入 したときのしゃ断現象を検討するには，乙の過渡特性 を知る必要がある。大容量の奏設借について求めるの は容易ではないので，順序として小形鉄心インダクタ ンスの $B-H$ 静特性, 飽和領域の直流過渡電流特性の 夷験を行ない， $B-H$ 静特性からの過渡現象計算結果 と比較して計算法の実用性を確認し，乙机志順次大形 のものに㹡張することとした。すなわち小形鉄心コイ ルによる実験之計算の比較から，静的な飽和特性より 折線近似での過渡電流計算の見通しが得られたので， 比较的小容量（定格 $1 \mathrm{kA}$ ) の実設備(リアクトル) に ついて試験，計算を行なった。そしてさらに大容量の 計算を行なうこととした。

（1）リアクトルの飽和特性供試リアクトル2 個でブリッジ回路を形成し，直流 $(0 \sim 6,000 \mathrm{~A})$, 交流 $50 \mathrm{~Hz}(20 \sim 30 \mathrm{~A})$ 在重量させて飽和特性を測定した。 （付録 III 参照)第 5 図化結果示す。

（2）リアクトル回路の直流過渡電流前項のリ アクトルを直流高生 $(1,500 \mathrm{~V})$ 回路(不飽和インダク タンス $0.5 \mathrm{mH}$ を含む) に民う入し, 推定短絡電流 4 〜 $50 \mathrm{kA}$ の範围で直流過隇電流の測定を行なうととも に，飽和特性からの計算值との比較を行なった。計算 手順としては,

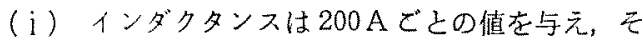
の閏は直線近似によった。

（ii）じゅうぶん小さな時間 $\Delta T$ に対する電流增 加分を $\Delta I$ とす机ば

$$
E=L(I) \cdot \Delta I / \Delta T+R I
$$

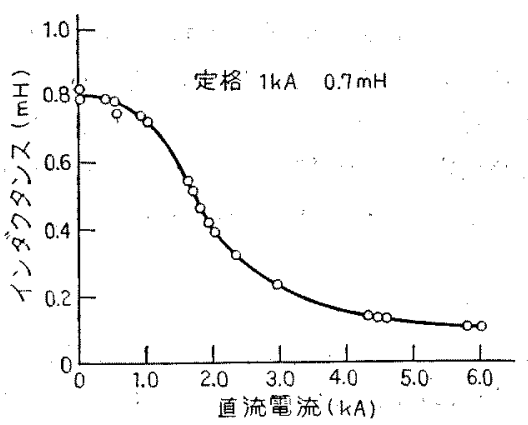

第 5 図 供試りアクトルの飽和特性

Fig. 5. Saturation curve of test reactor.

が成立するので， $\Delta T$ を $0.1 \mathrm{~ms}$ とし， $I=0$ より計 算老開始し

$$
\begin{aligned}
& \Delta I=(E-R I) \Delta T / L(I) \\
& I=I+\Delta I
\end{aligned}
$$

として $\Delta T$ ごとの電流 $I$ を求めた。ただし $E ， R$ は回路の電圧，抵抗，L(I) は可飽和インダクタンス と電源の不飽和インダクタンスの和で，電流の関数で ある。結果は

（a）推定短絡電流 $11 \mathrm{kA}$ 程度までは不飽和領域， 飽和領域を通じ，インダタタンスを測定値の 1.15 倍 程度にすると，電流波形の測定値上計算值位上く一政 する。とれは最初実験を行なった小形鉄心コイルの場 合と似た傾向である。

（b）前項の原因はインダクタンス测定值が直流に 微小交流を重畳して測定した増分透磁率化相当するも のであり，直流による磁化特性の傾斜より一般飞小さ いためと考えられる。

（c） 飽和が大なるはど，上の現象は少なくなるの て，大なる飽和領域を問題とするときは測定值をえの まま使用すべきです万う。すなわち，今回の実験に使 用したリアクトル定格 $1 \mathrm{kA}$ 亿対し推定短絡電流が相 対的に非常に大きい $30 \mathrm{kA} ， 50 \mathrm{kA}$ の場合は测定值老 このまま用いたはうが電流波形はよく一致した。(第 6 図)

（3）可飽和インダクタンス回路のしゃ断現象

可飽和インダクタンスとしてのリアクトルそう入の 効果確認のため，二宮実験所で可能な範图の条件でし や断試験を行なった（第 7 图〜第 9 図）要約す㧈ば，

（i）リアクトルそう入により実しゃ断電流岄小 なる。

（ii）アークパワは推定短絡電流が大なる領域で小 となる。

（iii）アークエネルギーはやや增大するが，不飽和 インダクタンス $1 \mathrm{mH}$ に比較すれば小さい。また推定 


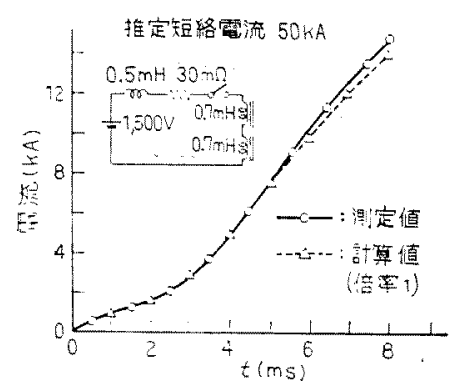

第 6 㘡 可館和インダクタンス回路の直流過渡電流

Fig. 6. DC transient current in saturatable inductance circuit.

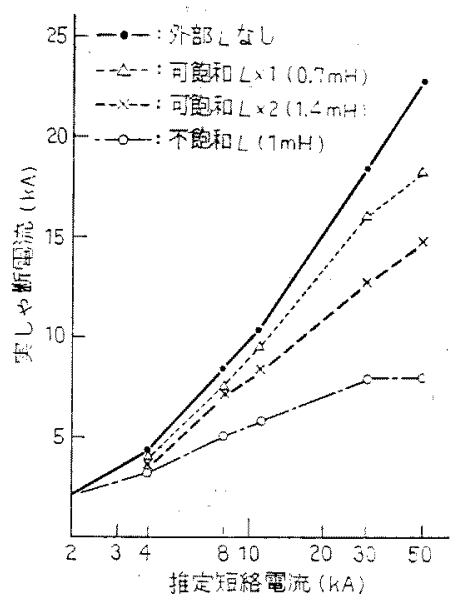

第 7 図 可飽和インダクタンス回路のしゃ断現象 (その 1 )

Fig. 7. Interrupting phenomena in saturatable inductance circuit. (1)

短絡最大 $(50 \mathrm{kA})$ 条件では、インダクタンスに上る 差はほとんどない。

すなうち，可飽和インダクタンスそう入により，丁 ークエネルギーはやや増大する場合があるが，奏しゃ 断電流とアークパワの㧕制効果があることが確想でき た。ここで大容量変電所にお晾る效果を推定するには 計算によるほかないので，上記実駼結果之計算結累の 比較を行ない，可飽和インダクタンス回路のしゃ断現 象計算法の妥当性を確認するとととする。計算上最も 問題之なるのはしゃ断器の開極特間を支配する選択率 をどのように与えるかである。すなわち，選択率は回 路定数により定まるが，その回路定数が飽和により変 化することになるわけである。ここでは選択率は以下 の方法で与えた。

（i）しゃ断器の目盛值之最終選规率の積任相当す る電流值すなわち最小動作電流值住対応するインダク タンス $L$ を求め $\alpha=R / L(R$ は回路抵抗) に対态す

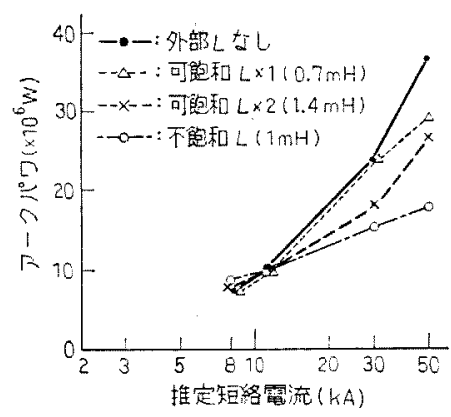

第 8 図可飽和インダクタンス回路のしゃ断現象 (その 2)

Fig. 8. Interrupting phenomena in saturatable inductance circuit. (2)

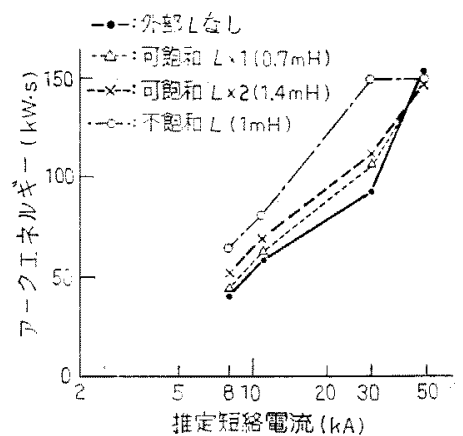

第 9 図 可飽和インダクタンス回路のしょ断現象 (天の 3)

Fig. 9. Interrupting phenomena in saturatable inductance circuit.

る選択率をこの回路条件での選択率とする。

(ii）したがって，求めた選択率に相当する電流值 (開極の基準点) に達したときの真の $\alpha$ は飽和により 前項の值を上回ることがありうるがこれは無視する。

以上の方法に上る計算結果を第 10 図に波形例を第 11 図に示す。すなわ方，実験值と多小の差はあるが，

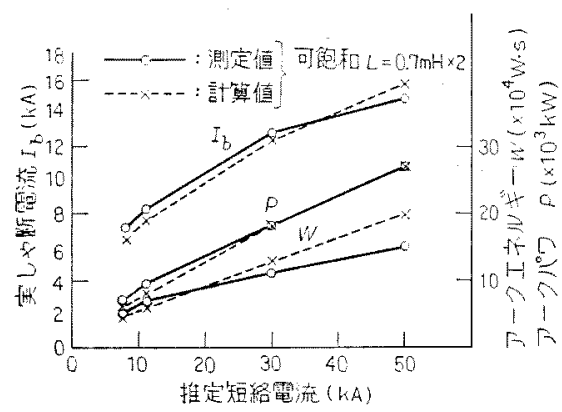

第 10 図 可飽和インダクタンス回路の Lゅ断現象計算

Fig. 10. Calculation of interrupting phenomena in saturatable inductance circuit. 


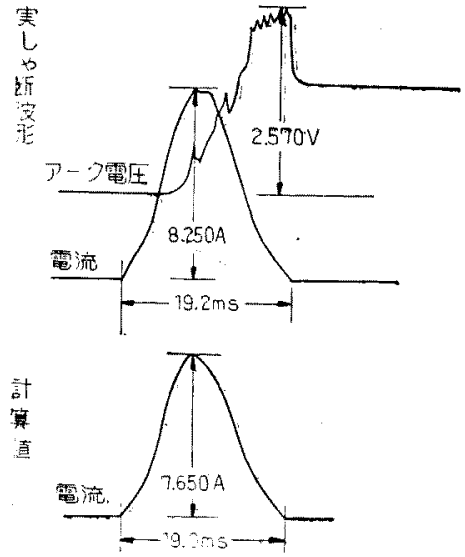

第 11 図 可飽和インダクタンスしゃ断 $(0.7 \mathrm{mH} \times 2,11 \mathrm{kA})$

Fig. 11. Interruption with additional saturatable inductance.

電流波形，実しゃ断電流，アークパワ，アクエネルギ 一などほぼ近似の結果が得られ，可飽和インダクタン スそう入によりしゃ断が容易となるか否かの判断を下 すうえには，この計算法でじゅうぶえと考えられる。

（4）大容量設備に対する計算 し中断器の定格 をこえる短絡電流が流机る箇所化可飽和インダクタン ス，たとえばフィルタ用リアクトルをそう入したとき の効果它計算する。一般使用されているフィルタ用 リアクトルの飽和特性は定格電流で $1.1 \mathrm{mH}$ 以上, $150 \%$ に対して $1 \mathrm{mH}$ 以上のほかは規定されていない ので，数種のすのにつての調査結果より最屯飽和し

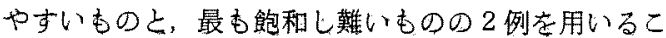
ととした。(第 12 図参照)計箅条件としては，下記に よるほかはいままで述べた方法によった。

（i） 不䳌和時のインダクタンヌ值は $1.37,1.1$, $0.55 \mathrm{mH}$ の 3 種

(ii) 変電所内部インダクタンスは $0.2 \mathrm{mH}$ ，同内 部抵抗は $0.03 \Omega, 0.015 \Omega$ とする。

（iii）事故発生直前のしゃ断器電流，すなわ方，底

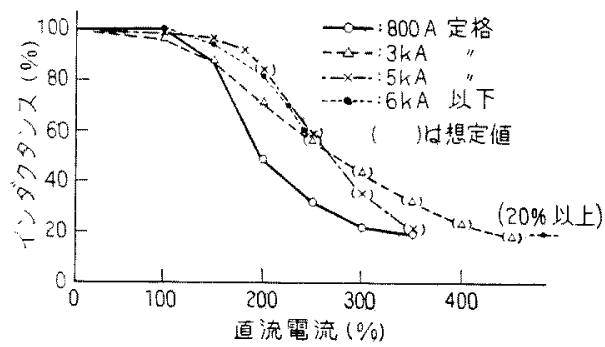

第 12 图 フィルタ用りアクトルの飽和特性

Fig. 12. Saturation curves of filter reactors.

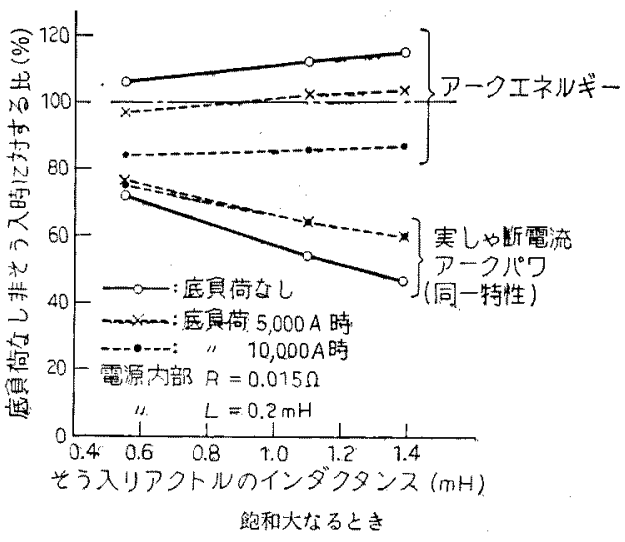

第 13 図 フィルタ用りアクトルそう入時の しゃ断現象（その1)

Fig. 13. Interrupting phenomena with additional filter reactor.

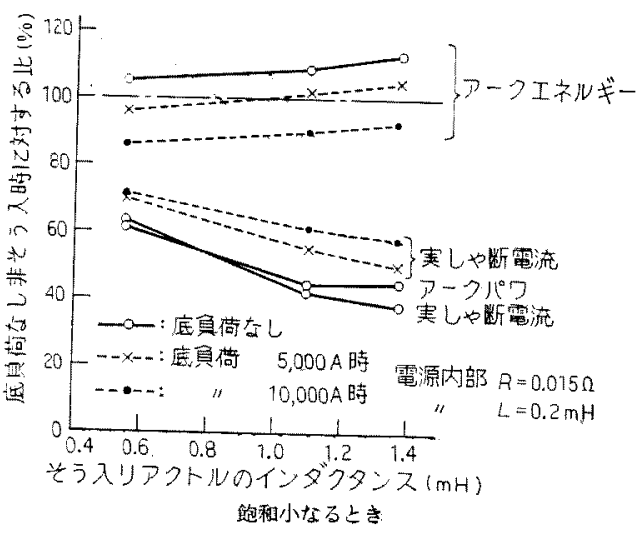

第 14 図フィルタ用リアクトルそう入時の しゃ断現象 (その2)

Fig. 14. Interrupting phenomena with additional filter reactor.

負荷は $0 \mathrm{~A}, 5,000 \mathrm{~A} ， 10,000 \mathrm{~A}$ とする。

計算結果の 1 部を第 13 図，第 14 図に示す。また 計算波形例を第 15 図に示す。要約すれば

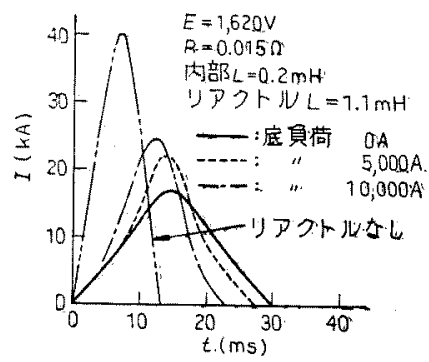

第 15 図 可飽和インダクタンスそう入時の Lp断電流波形（計算值）

Fig. 15. Caleulated wave shapes of intermpting current with additional saturatable inductance. 
(i) リアクトルそう入により実しゃ断電流（限流 值),アークパワは非そう入時底負荷なしの場合の約 40〜80\%に減少し，その效果はインダクタンス值の大 なるほど大きい。

（ii）アークエネルギーはやや增大するが，推定短 絡電流が大なるときはすずかである。(最大 $15 \%$ 増程 度)

（iii）標準的な $0.03 \Omega, 0.5 \mathrm{mH}$ (不飽和) 時比比 䩙すればアークパワ，実しゃ断電流，アークエネル ギーとも增大するが， $0.55 \mathrm{mH}$ (可飽和) を除けば， 実しゃ断電流は仕梯 $(25 \mathrm{kA})$ 以下であり，アークパ ワ，アークエネルギーも交流等価試験時の最大值を下 回っているので，現用しゃ断器でのしゃ断はじゅうぶ ん可能と考えられる。

(iv）不飽和インダタタンスと比較すれば，アーク パワ，アークェネルギーとあやや大きいが，そう入に 上る効果はじゅうぶん大きい。ただし特に小なるイン ダクタンスをそう入するときは不飽和とし，全直流イ ンダタタンス值が $0.5 \mathrm{mH}$ 以上となるよう配慮したは うがよい。

\section{4. むすひ}

以上，大容量直流変電所の短絡電流を明らかにする とともに，その対策としては母線分離が望ましいがて れが不可能な場合にインダクタンスそう入による方法 の検討を行なった。要約すれば次のとおりである。

(1) 短絡電流立上りを支配する6のは，変電所内 部インダクタンス之変電所より第 1 き電分岐までの1 ンダクタンスで，後者は導体の幾何学的配置で計算で きる。両者の合計は計算例では $0.17 \sim 0.47 \mathrm{mH}$ であ った。

（2）同様にして等価短絡電流は 60 100 kA 亿達 Lt。

（3）初期立上り (di/dt) の大なる大電流のしゃ 断では，インダクタンスそう入によりアークエネルギ 一ははとんど変化せず，アークパワ限流值（実しゃ断 電流）が大はばに抑制される効果がある。

（4）そう入インダクタンスに可飽和のものを使用 しても前項に近い効果がある。

いずれにしても大容量直流変電所の大なる短絡電流 に対しては，まず母線分雕をすべきであり，それが不 可能である場合には上記のインダクタンスをそう入す る方法によるのが適切であるう。

最後にこの研究注対し終始ご指導ご協力頂きました 鉄道電化協会直流回路委員会山村 昌委員長はじめ委 員の方々に樑謝致します。また，各種害地試験には当
研究室 本多, 諏訪部, 古沢, 元当研究室 島田の諸氏 の多大の助力を受计たのでとてに謝意を表します。

(昭和 47 年 8 月 16 日受付, 同 48 年 2 月 6 日再受付)

\section{文献}
(1) 藤村：電笑学会諭文站 93-B，256 (炤 48-6)

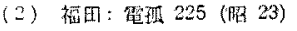
(3) E Grunefeld \& H. Schulz: Siemens Zeitschrift 43, 2, 80 (1969)

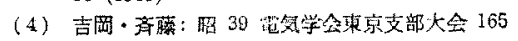

\section{付 録}

I $n$ 本と $m$ 本（それそれ同一寸法）の草体より なる往復回路のインダタタンス（付第1图参照）

半径 $r$, 導体間隔 $D_{i j}$ Q $n$ 本の各導体仿同一電流 $I_{0}$ が流机るとすれば， $n$ 本の導体化蓄无ら机る電磁 エネルギーWは次式で示される。

$$
W=\frac{1}{2} I_{0}^{2}\left(n L_{0}+2 \sum_{i=1}^{n} \sum_{j=1}^{n} M_{i j}\right)(i \neq j)
$$

ただし，L峉導体の自己インダクタンス）

$$
=2(\log 1 / r+1 / 4) \times 10^{-4} \mathrm{H} / \mathrm{km}
$$

$M_{i j}$ (導体 $i, j$ 間の相互インダィタンス)

$$
=2 \log 1 / D_{i j} \times 10^{-4} \mathrm{H} / \mathrm{km}
$$

$n$ 本の導体をL。なる自己インダクタンスを持つ往 復捋体の片倒としての1本の導体（等価導体）に置き かえれば

$$
\begin{aligned}
& W=\frac{1}{2} L_{e}\left(n I_{0}\right)^{2} \\
& \left.\therefore L_{e}=\frac{2 W}{n^{2} I_{0}^{2}}=\frac{L_{0}}{n}+\frac{2}{n^{2}} \sum_{i=1}^{n} \sum_{j=1}^{n} M_{i j} \text { (付 } 2\right)
\end{aligned}
$$

等価導体のインダクタンス $L$ 。 が（付 3 ) 式で表わ さ机ると仮定すれば，(付 2 )式より（付 4 ）式が得ら 机る。

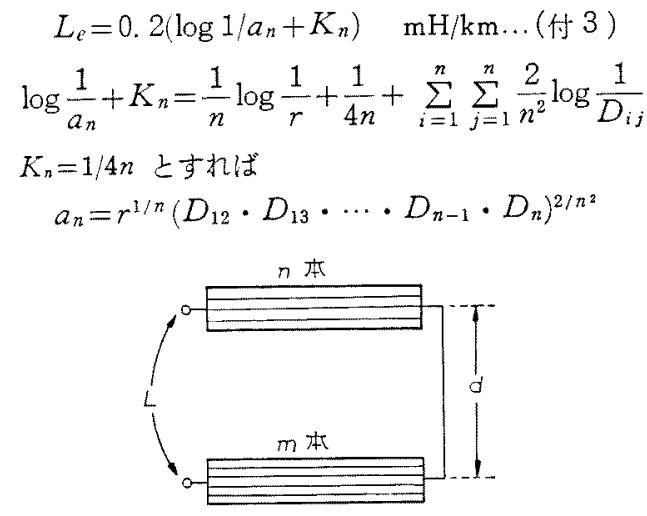

付第 1 図 複数導体の等価インダクタンス app. Fig. 1. Equivalent inductance of conductors. 


$$
(i \neq j) \ldots \ldots \ldots \ldots \ldots \text { (付 } 4)
$$

ここに $a_{n}$ を等洒半堡と名づける。したがって，n 本導体， $m$ 本導体 (等価半径 $b_{m}$ ) 上りなる往復回路 (間隔 $d$ ) のインダクタンスは

$$
\begin{array}{r}
L=\left\{0.4 \log \left(d / \sqrt{a_{n} b_{m}}\right)+0.05(1 / n+1 / m)\right\} \\
(\mathrm{mH} / \mathrm{km}) \ldots \ldots \ldots \ldots \ldots \ldots \text { (付 } 5)
\end{array}
$$

II $l$ なる長さの $n$ 本鿓体が単独に存在するとき のインダクタンスとの場合も, 前項と同じ考え方 で（付 1 )式が成立する。ただし，この場合

$$
\begin{aligned}
& L_{0}=2 l\{\log 2 l / r-1+1 / 4\} \times 10^{-4}(\mathrm{mH}) \\
& M_{i j}=2 l\left\{\left\{\log 2 l / D_{i j}-1\right\} \times 10^{-4}(\mathrm{mH})\right.
\end{aligned}
$$

$n$ 本の導体を L。なる自己インダクタンスを持つ 1 本の単独導体 (等価導体) に置きかえ机ば，同様にし て（付 2）式が成立する。そして Le 加（付 6) 式 で表わされると仮定すれば

$$
\begin{aligned}
L_{e}=2 l\left\{\log \left(2 l / a_{n}\right)+J_{n}\right\} \times 10^{-4} \mathrm{mH} \text { (付6) } \\
\begin{aligned}
\log \frac{2 l}{a_{n}} & +J_{n}=\frac{1}{n} \log \frac{2 l}{r}-\frac{3}{4 n}+\frac{2}{n^{2}} \sum_{i=1}^{n} \sum_{j=1}^{n}\left\{\log \frac{2 l}{D_{i j}}\right. \\
& -1\} \\
& =\frac{1}{n} \log \frac{2 l}{r}+\frac{2}{n^{2}} \sum_{i=1}^{n} \sum_{j=1}^{n} \log \frac{2 l}{D_{i j}}-1+\frac{1}{4 n}
\end{aligned}
\end{aligned}
$$

となり， $J_{n}=-1+1 / 4 n$ と置くことにより， $a_{n}$ 加同 様に（付 4) 式で与无られ，したがって， $n$ 本賏体が

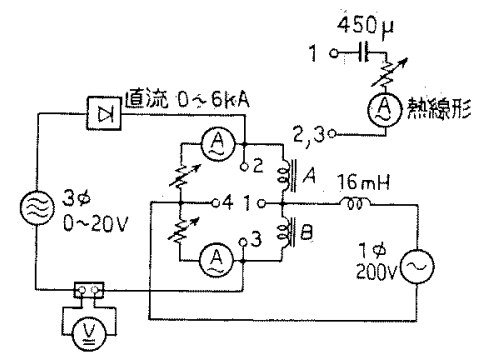

付第 2 図リアクトル飽和特性測定回路 app. Fig. 2. Measuring circuit of saturation curve of reactor.

単独に存在するときのインダクタンスは

$$
L=2 l\left\{\log \left(2 l / a_{n}\right)-1+1 / 4 n\right\} \times 10^{-4}(\mathrm{mH})
$$

前項とともに $n$ 本が並列となったととにより，内部 インダクタンスが $1 / n$ になったと見なせる。

III 可飽和リアクトル飽和特性の測定 付第 2 図 に示すように，A，B2籄のリアクトルと抵抗でブリ ッジを形成し，各直流電流住対し直流バランスをとり， これ交流を重畳させ，リアクトル端子電圧(実効値) を測定した。なお，直流電流には高調波が含ま机てい るので，重畳時の端子電圧 $V_{s}$, 直流のみ流したとき の高調波による端子電圧 $V_{H}$ より $\left.V=\sqrt{V_{s}{ }^{2}-V_{H^{2}}}\right]$ として真值を求めた。 